\title{
Pengaruh Variasi Kecepatan Hembusan Udara Terhadap Temperatur, Daya Output dan Efisiensi Pada Pendinginan Panel Surya
}

\author{
Gunawan Rudi Cahyono ${ }^{1 *}$, Pathur Razi Ansyah ${ }^{2}$, Muhammad Munthaha ${ }^{3}$ \\ ${ }^{1,2,3}$ Program Studi Teknik Mesin, Universitas Lambung Mangkurat \\ 1,2,3 Jl. Jenderal Achmad Yani KM 35,5 Kota Banjarbaru, 70714, Indonesia \\ E-mail: gunawan.cahyono@ulm.ac.id ${ }^{1}$, pathur.razi@ulm.ac.id ${ }^{2}$, mhmmdmunth@gmail.com ${ }^{3)}$
}

\section{Info Naskah:}

Naskah masuk: 14 Juni 2020

Direvisi: 27 Juli 2020

Diterima: 13 Agustus 2020

\begin{abstract}
Abstrak
Pesatnya perkembangan teknologi, cahaya matahari mampu diubah menjadi energi listrik. Namun ada permasalah yang timbul dalam kinerja panel surya, salah satunya yaitu temperatur panel yang terlalu tinggi. Oleh karena itu untuk mengatasi penurunan performa, temperatur panel perlu dijaga. Dalam eksperimen ini bertujuan untuk menganalisis pengaturan temperatur pada pendinginan panel surya menggunakan variasi kecepatan udara guna peningkatan performa photovaltik. Eksperimen menggunakan simulator surya dan dilakukan dalam kondisi ruang tertutup. Satu buah panel surya yang ditempatkan pada kotak khusus yang disebut kotak pendingin dan diberikan empat buah termokopel dibagian atas panel dan 2 buah lainnya di bagian bawah panel untuk mengevaluasi kenaikan temperature yang terjadi pada panel. Blower udara dikombinasikan dengan anemometer untuk memberikan variasi kecepatan udara untuk pendinginan panel. Dari hasil pengujian panel surya tanpa pendinginan didapat pada kisaran temperatur $38-52,875^{\circ} \mathrm{C}$ menghasilkan efisiensi listrik yang berkisar 3,014$3,134 \%$. Sedangkan pada pengujian menggunakan pendinginan dengan kecepatan udara bervariasi yaitu 2, 3, 4 dan $5 \mathrm{~m} / \mathrm{s}$ pada kisaran temperatur $33,43-40,5^{\circ} \mathrm{C}$ menghasilkan efisiensi listrik yang berkisar dari 3,106-3,206\%
\end{abstract}

Keywords:

solar panel;

cooling;

temperature;

output power;

efficiency.

\section{Abstract}

The rapid development of technology, sunlight can be converted into electrical energy. But there are problems that arise in the performance of solar panels, one of which is the panel temperature is too high. Therefore to overcome the decrease in performance, the panel temperature needs to be maintained. In this study aims to analyze the temperature settings on solar panel cooling using variations in air velocity to improve photovaltic performance. Solar simulators is used in this ekperiment and carried out in a closed room conditions. solar panel is placed in a special box called a cooler box and four thermocouples are placed at the top of the panel and 2 others at the bottom of the panel to evaluate the temperature changes that occurs on the panel. An air blower is combined with an anemometer to provide variations in air velocity for cooling the panels. From the results of solar panel testing without cooling obtained in the temperature range of 38 $52.875^{\circ} \mathrm{C}$ produces electrical efficiency ranging from $3.014-3.134 \%$. Whereas in testing using cooling with varying air velocity of $2,3,4$, and $5 \mathrm{~m} / \mathrm{s}$ in the temperature range of $33.43-40.5^{\circ} \mathrm{C}$ produces electrical efficiency ranging from $3.106-3.206 \%$. 


\section{Pendahuluan}

Sumber daya alam Indonesia semakin menipis dikarenakan konsumsi energi yang secara terus menerus namun tidak dapat diperbaharui (Unrenewable resources)[1]. Perlu adanya solusi energi sebagai penggati ketergantungan terhadapa sumber daya alam tersebut. Salah satu yang bisa dimanfaatkan potensinya di Indoneisa adalah Energi Surya. Energi surya menjadi alternatif energi ramah lingkungan, bebas polutandan dapat menjadi salah satu energi masa depan[2] Karena posisi indonesia dilalui garis khatulistiwa, sehingga potensi untuk memnfaatkan energi dari hasil konversi cahaya matahari dapat mempunyai potensi yang besar.

Cahaya matahari mempunyai spektrum sinar mulai dari sinar ultraviolet sampai near-infrared. Intensitas radiasi matahari di luar atmosfer bumi disebut konstanta surya, yaitu sebesar $1365 \mathrm{~W} / \mathrm{m} 2$. Setelah disaring oleh atmosfer bumi beberapa spektrum cahaya hilang, dan intensitas puncak radiasi menjadi sekitar $1000 \mathrm{~W} / \mathrm{m}^{2}$ atau 100 $\mathrm{mW} / \mathrm{cm}^{2}$. Nilai ini menunjukan tipikal intensitas radiasi pada keadaan permukaan tegak lurus sinar matahari dengan keadaan cerah[3]. BEI (Bursa Efek Indonesia) mengemukakan bahwa perkembangan teknologi surya yang dapat dijangkau, tidak terbatas dan ramah lingkungan akan memberi benefit untuk kedepannya. Perkembangan teknologi energi surya akan menambah tingkat aman energi negara di dunia melalui pengunaan sumber energi yang telah ada, tidak harus mengurangi polusi, mengurangi biaya mitiigasi perubahan iklim dan mengurangi penggunaan bahan bakar fosil.

Ada beberapa permasalah yang timbul dalam kinerja panel surya, salah satunya yaitu temperatur pada sel surya sangat mempengaruhi perpindahan elektron. Hal ini dikarenakan komponen semikonduktor pada sel surya sangat sensitif terhadap perubahan temperatur. Ketika temperatur semakin naik, maka band gap (selisih atau celah energi antara pita valensi dengan pita konduksi) semikonduktor menurun, sehingga nilai resistansi semakin meningkat dan perpindahan elektron semakin melambat[3]. Hal ini berefek kepada penurunan performa dari panel surya tersebut. Banyak penelitian yang telah dilakukan untuk dapat membuang panas berlebih tersebut. Beberapa menggunakan metode eksperimen[5]-[8], numerik[9] dan hasilnya peningkatan temperatur dari panel surya dapat mengurangi kinerja panel surya tersebut.

Pengembangan sistem pendinginan menjadi salah satu cara mengatasi permasalahan temperatur pada panel surya telah dilakukan[8],[10-12]. Sistem pendingin yang digunakan bisa menggunakan media air baik itu air laut, air mineral, atau butiran air (water Spray) [6], [12]. Kebanyakan penelitian pendingin ini dilakukan menggunakan metode ekperimen maupun simulasi. Media Pendingin[6] menggunakan water spray dapat meningkatkan efisiensi daya ouput dari panel surya sekitar $16.3 \%$ dan menaikan efisiensi panel sebesar $14,1 \%$ hal ini karena pendinginan dilakukan secara total baik itu bagian permukaan maupun bagian bawah panel surya. Media pendingin berupa material yang dapat berubah fase atau disebut phase change material (PCM) dikombinasikan dengan media udara juga telah dilakukan[7]. Hasilnya, penurunan temperature panel yang terjadi sebesar $3-5^{\circ} \mathrm{C}$, dan hal ini memberikan dampak kepada peningkatan efisiensi listrik dan daya keluaran dari panel surya. Panas yang diserap oleh PCM dapat digunakan kemudian untuk aplikasi lainya karena prinsipnya PCM dapat menyimpan panas yang diterima[13]. Pada penelitian lainnya, media air dialirkan melalui pipa berdiameter kecil diletakkan berdempetan dibagian bawah panel surya sebagai heat sink juga menunjukkan hasil pelepasan panas dari panel surya sebesar $1 \mathrm{~kW}$ dan dapat menurunkan temperature panel sekitar $40^{\circ} \mathrm{C}[14]$. Media udara sebagai upaya peningkatan performa panel telah dilakukan. Dalam penelitian ini panel surya temperatur maksimum permukaan dalam panel surya tanpa pendinginan berkisar $46-49^{\circ} \mathrm{C}$, dan efisiensi listrik berkisar 6,1-6,7 \%. Sedangkan untuk panel surya dengan pendinginan menggunakan media udara, temperatur maksimum permukaan hanya mencapai $42^{\circ} \mathrm{C}$, dan efisiensi meningkat menjadi 7,0-7,8\%.[15].

Dari berbagai penelitian yang telah disebutkan, pendinginan panel surya sangat tergantung dari media pendingin yang digunakan. Pendinginan panel surya dengan media udara sangat dipengaruhi oleh kecepatan udara. Sedangakan kecepatan udara pada kondisi luar ruangan, dapat dipengaruhi oleh cuaca dan ketinggian. Variasi ketinggian mulai 1 sampai dengan 30 meter, menghasilkan hembusan udara bervariasi mulai dari $1 \mathrm{~m} / \mathrm{s}$ sampai dengan $4.7 \mathrm{~m} / \mathrm{s}$.[16]. Selain itu, ketika penempatan panel surya pada atap bangunan dengan ketinggian tertentu ataupun pada atap mobil listrik saat posisi berjalan, dapat mempengaruhi kecepatan hembusan udara. Sehingga perlu dilakukan pengamatan efek kecepatan udara lebih lanjut pada performa pendinginan panel apabila diaplikasikan.

Faktor lain yang perlu diperhatikan adalah pengaturan posisi sumber panas dan intensitas radiasi yang tetap dan tegak lurus terhadap panel surya akan memberikan sebaran yang merata ke seluruh permukaan bidang dan energi yang dihasilkan dapat maksimal [17]. Walaupun telah banyak penelitian yang dilakukan terkait pendinginan panel surya ini, namun belum ada yang menggunakan kotak pendingin yang sederhana, bisa diaplikasikan dimanapun dan siapapun. Maka, dengan mempertimbangkan adanya perubahan kecepatan udara, tipikal intensitas radiasi cahaya maksimum yaitu tegak lurus pada permukaan panel surya dan modifikasi terhadap kotak pendingin yang lebih sederhana, maka penanggulangan panas yang berlebih menggunakan media udara, dengan memberikan cvariasi kecepatan udara terhadap panel surya sehingga dapat meningkatkan eisiensi dan daya keluaran panel surya sangat perlu dilakukan.

\section{Metode Penelitian}

Penelitian ini menggunakan alat dan bahan yaitu Panel Surya 50 WP, 2 buah Lampu Sorot dengan daya 500 Watt sebagai solar simulator, Triplek dengan ukuran $700 \mathrm{~cm} \mathrm{x}$ $1125 \mathrm{~cm}$ dan tebal $3 \mathrm{~mm}$ sebagai kotak pendingin, Pipa dengan diameter $5 \mathrm{~cm}$ sebagai saluran masuk yang dihubungkan dengan Blower udara, Anemometer untuk mengukur kecepatan udara, Micro Controller dan Sensor temperatur untuk mengaluasi perubahan temperatur panel, Luxmeter mengukur besarnya intesitas cahaya dan 
Avometer untuk mengukur arus dan tegangan listrik yang dihasilkan oleh panel secara periodik.

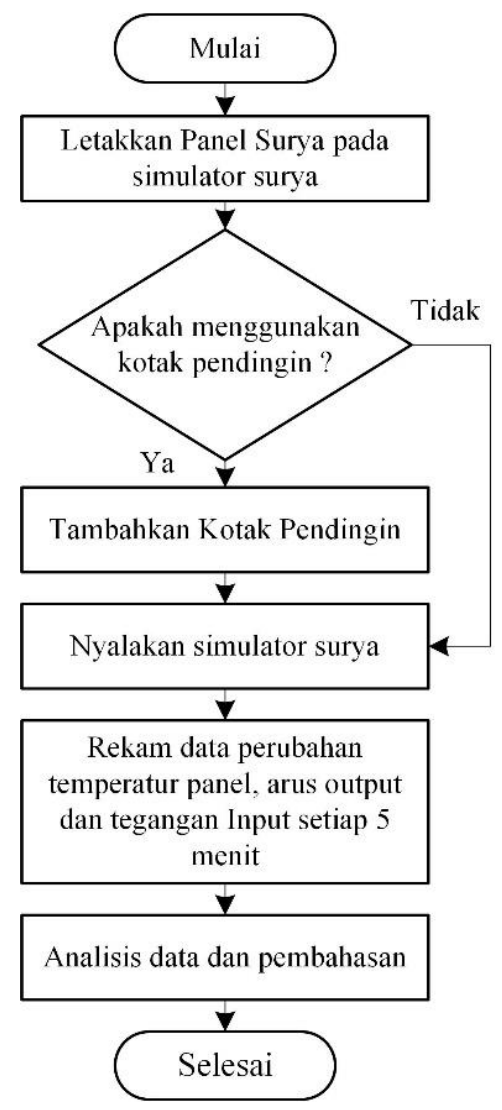

Gambar 1. Diagram Alir Penelitian

Pada Gambar 1 menjelaskan alur penelitian yang dilakukan. Panel surya di letakkan pada simulator surya tepatnya $40 \mathrm{~cm}$ di bawah simolator surya seperti terlihat pada Gambar 2. Solar simulator dihidupkan selama 25 menit. Temperatur terus dipantau menggunakan sensor temperatur secara preodik.

Udara pendingin di hembuskan menggunakan blower dengan variasi kecepatan 2, 3, 4, dan 5 m/s. Pada kondisi tanpa kotak pendingingan, blower dimatikan. Kemudian, arus dan tegangan output panel surya diukur setiap 5 menit.

\subsection{Analisis Performa Panel Surya}

Dengan merujuk pada penelitian [4] Menentukan efisiensi listrik $(\eta)$ panel surya didasarkan pada persamaan (1).

$$
\eta_{l}=\frac{\mathrm{vi}}{\mathrm{GA}_{\mathrm{p}}} \times 100 \%
$$

Dimana $\eta$ adalah efisiensi listrik rangkaian panel surya, $\mathrm{V}$ adalah tegangan (V), I adalah arus, G adalah intensitas radiasi $\left(\mathrm{W} / \mathrm{m}^{2}\right)$, dan Ap adalah luas permukaan panel surya $\left(\mathrm{m}^{2}\right)$.

Untuk menghitung irradiasi dari cahaya lampu yang digunkan pada solar simulator menggunakan persamaan (2).

$$
G=\frac{L v}{K}
$$

$\mathrm{Lv}$ adalah Luminous Intensity $\left(\mathrm{lm} / \mathrm{m}^{2}\right), \mathrm{K}$ adalah Luminous Efficacy $(\mathrm{lm} / \mathrm{W})$.

Pada Gambar 3 menampilkan instalasi kotak pendingin dan panel surya. Pada kotak pendingin terdapat sirip pengarah agar udara yang melawati kotak dapat langsung menyentuh bagian bawah panel surya.

\section{Hasil Dan Pembahasan}

Tabel 1 menunjukkan hasil perhitungan berdasarkan rumus (1) dan (2) pada pengujian tanpa kotak pendingin, pengujian menggunakan pendingin udara dengan kecepatan masing-masing 2, 3, 4, dan $5 \mathrm{~m} / \mathrm{s}$.

Dalam penelitian ini membahas pengaruh perubahan kecepatan udara terhadap temperatur dan daya output yang dihasilkan, sehingga dibuat grafik seperti pada Gambar 4.

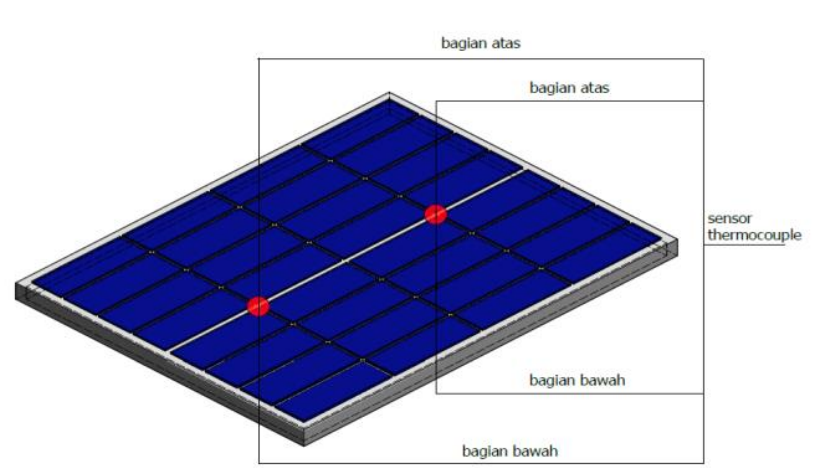

(a)

Gambar 2. (a), (b) Simulator Panel Surya

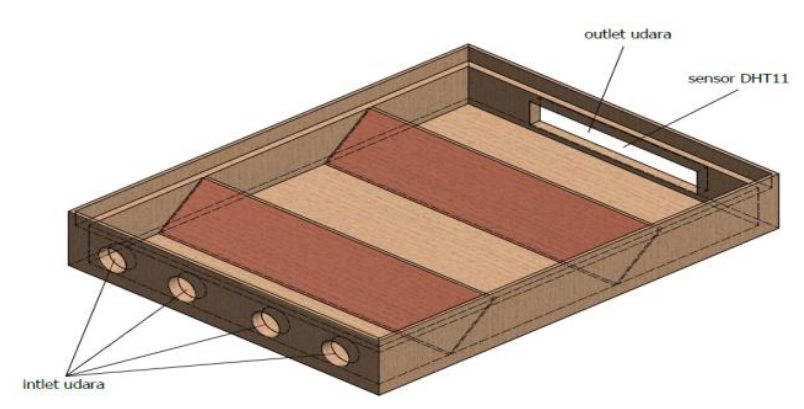

(b) 


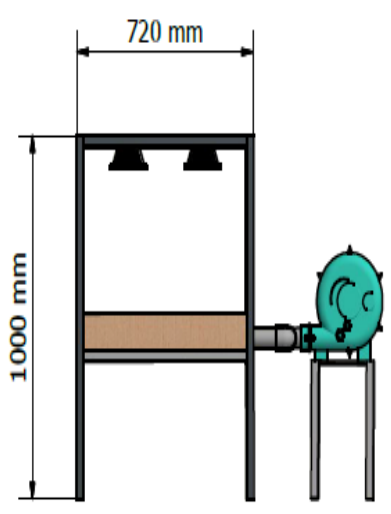

(a)

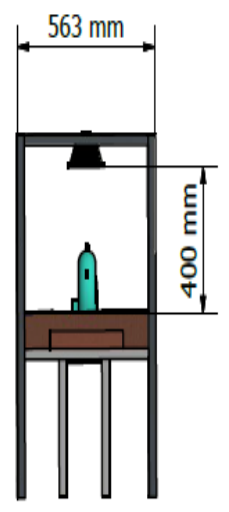

Gambar 3. (a), (b) Instalasi Kotak Pendingin dan Panel Surya
Tabel 1. Hasil perhitungan performa panel surya

\begin{tabular}{ccccc}
\hline Pengujian & $\begin{array}{c}\text { Ts } \\
\left({ }^{\circ} \mathbf{C}\right)\end{array}$ & $\begin{array}{c}\text { Daya } \\
(\mathbf{w a t t})\end{array}$ & $\begin{array}{c}\mathbf{G} \\
\left(\mathbf{W} / \mathbf{m}^{2}\right)\end{array}$ & $\begin{array}{c}\text { Efisiensi } \\
\text { Listrik } \\
(\mathbf{\%})\end{array}$ \\
\hline Tanpa Kotak & 38 & 3,29 & 278 & 3,134 \\
Pendinginan & 40,55 & 3,26 & 278 & 3,103 \\
& 43,875 & 3,22 & 278 & 3,069 \\
& 47,875 & 3,20 & 278 & 3,048 \\
& 50,75 & 3,18 & 278 & 3,026 \\
Pendinginan & 52,875 & 3,16 & 278 & 3,014 \\
(2m/s) & 33,75 & 3,34 & 278 & 3,185 \\
& 36,1 & 3,32 & 278 & 3,158 \\
& 37,8 & 3,29 & 278 & 3,137 \\
& 39,25 & 3,28 & 278 & 3,120 \\
Pendinginan & 40,125 & 3,27 & 278 & 3,113 \\
$(3 \mathrm{~m} / \mathrm{s})$ & 40,5 & 3,26 & 278 & 3,106 \\
& 33,62 & 3,35 & 278 & 3,192 \\
& 35,5 & 3,32 & 278 & 3,166 \\
& 37,2 & 3,30 & 278 & 3,146 \\
& 38 & 3,29 & 278 & 3,134 \\
Pendinginan & 38,95 & 3,28 & 278 & 3,123 \\
$(4 \mathrm{~m} / \mathrm{s})$ & 39,4 & 3,27 & 278 & 3,117 \\
& 35,54 & 3,36 & 278 & 3,199 \\
& 36,75 & 3,33 & 278 & 3,171 \\
& 37,25 & 3,31 & 278 & 3,151 \\
& 37,8 & 3,29 & 278 & 3,144 \\
Pendinginan & 38,25 & 3,29 & 278 & 3,137 \\
& 33,43 & 3,37 & 278 & 3,130 \\
& 34,85 & 3,33 & 278 & 3,175 \\
& 36,25 & 3,32 & 278 & 3,159 \\
& 36,5 & 3,31 & 278 & 3,154 \\
& 37 & 3,30 & 278 & 3,147 \\
& 37,6 & 3,30 & 278 & 3,141 \\
\hline & & & &
\end{tabular}

Pada Gambar 4 menunjukkan hubungan temperatur terhadap daya output panel berbanding terbalik. Pada kisaran temperatur $38-52,875^{\circ} \mathrm{C}$ merupakan grafik dari pengujian panel surya tanpa pendinginan dengan kisaran daya output sebesar 3,29-3,16 watt. Sedangkan pada kisaran temperatur $33,43-40,5^{\circ} \mathrm{C}$. merupakan grafik dari pengujian menggunakan pendinginan dengan hembusan udara bervariasi yaitu $2 \mathrm{~m} / \mathrm{s}, 3 \mathrm{~m} / \mathrm{s}, 4 \mathrm{~m} / \mathrm{s}$ dan $5 \mathrm{~m} / \mathrm{s}$ menghasilkan daya output sebesar 3,37 watt - 3,26 watt.

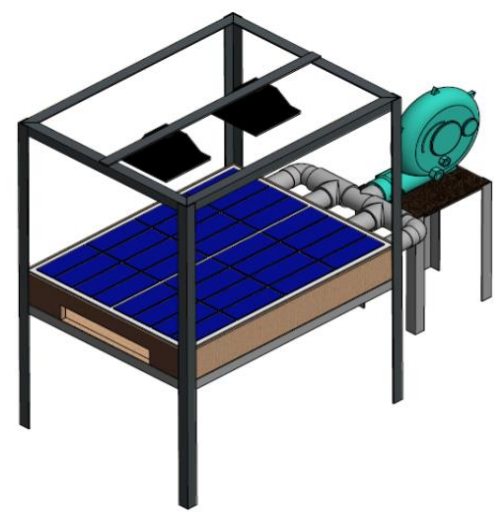

(b)

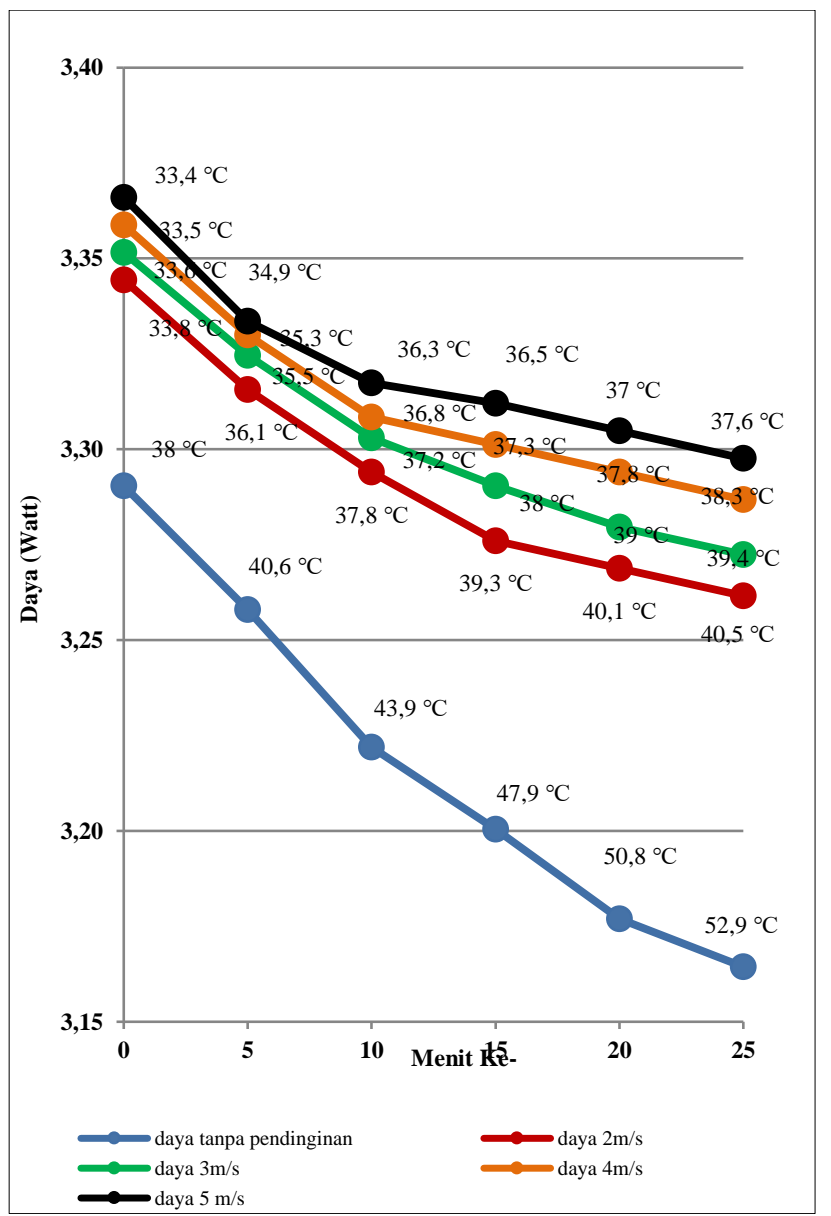

Gambar 4. Grafik Pengaruh Perubahan Kecepatan Udara Terhadap Temperatur Dan Daya Keluaran Yang Dihasilkan

Pada menit ke-5, temperatur panel surya tanpa pendinginan mencapai $40,6^{\circ}$ Cdengan daya sebesar 3,26 watt. pada menit yang sama dengan pendinginan kecepatan udara $2 \mathrm{~m} / \mathrm{s}$ temperatur turun menjadi $36,1{ }^{\circ} \mathrm{Cdengan}$ daya 
sebesar 3,32 watt. Dalam hal ini terjadi penurunan temperatur dan peningkatan daya yang lebih baik dengan kecepatan udara $3 \mathrm{~m} / \mathrm{s}, 4 \mathrm{~m} / \mathrm{s}$ dan $5 \mathrm{~m} / \mathrm{s}$. sehingga didapatkan penurunan temperatur paling besar 34,9 ${ }^{0}$ Cdengan daya sebesar 3,33 watt.

Apabila diambil sampel di menit ke-5 pada pengujian dengan menggunakan pendinginan kecepatan udara $2 \mathrm{~m} / \mathrm{s}$ ( teganagn $18,42 \mathrm{~V}$, arus $0,18 \mathrm{~A}$ ) daya output yang didapat adalah 3,316 watt sedangkan dengan menggunakan pendinginan kecepatan udara $5 \mathrm{~m} / \mathrm{s}$ ( teganagn $18,52 \mathrm{~V}$, arus $0,18 \mathrm{~A}$ ) daya output yang didapat meningkat menjadi 3,334 watt. Dapat disimpulkan bahwa semakin besar kecepatan udara maka daya output yang dihasilkan juga akan semakin besar. Hal ini dikarenakan temperatur panel turun seiring kenaikan kecepatan udara. Senada dengan hasil ini bahwa semakin efektif efek pendinginan panel maka semakin besar nilai tegangan yang didapatkan[6], [7]

Dalam hal ini juga membahas pengaruh perubahan kecepatan udara terhadap temperatur dan efisiensi yang dihasilkan, sehingga grafik sebagai berikut:

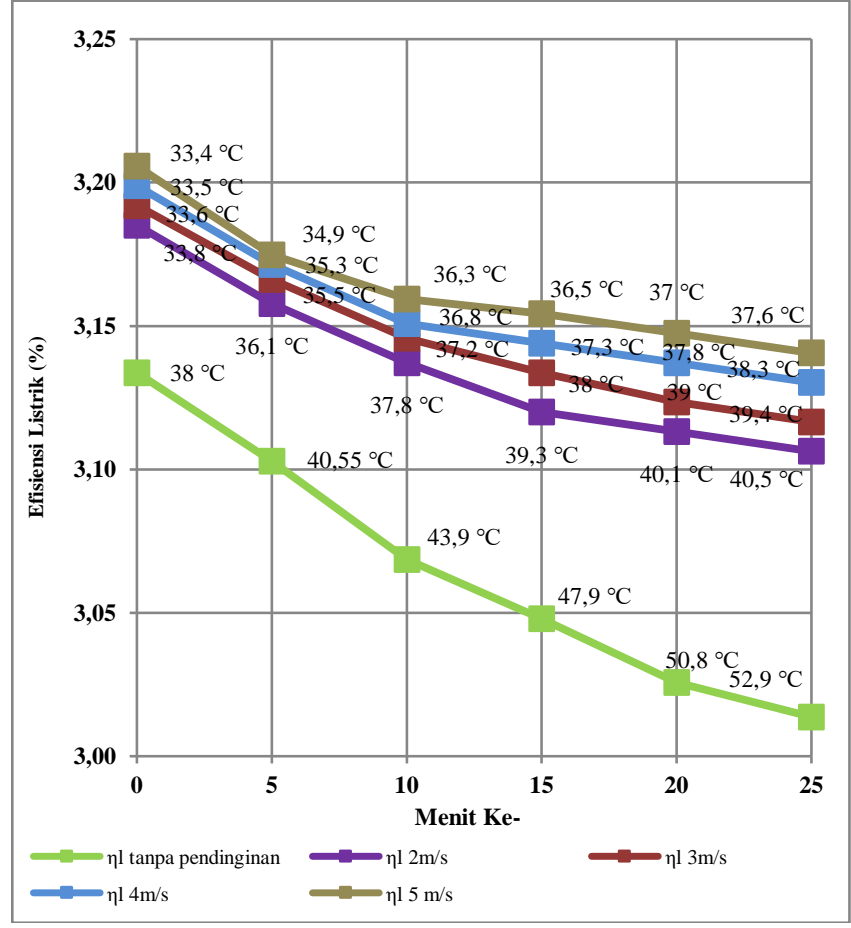

Gambar 5. Grafik Pengaruh perubahan kecepatan udara terhadap temperatur dan efisiensi yang dihasilkan

Gambar 5 menunjukkan hubungan temperatur terhadap efisiensi listrik panel surya berbanding terbalik. Pada kisaran temperatur $38-52,875^{\circ} \mathrm{C}$ merupakan grafik dari pengujian panel surya tanpa pendinginan dengan kisaran efisiensi listrik sebesar 3,134-3,014\%. Sedangkan pada kisaran temperatur $33,43-40,5^{\circ} \mathrm{C}$ merupakan grafik pengujian menggunakan pendinginan dengan kecepatan udara bervariasi yaitu 2, 3, 4 dan $5 \mathrm{~m} / \mathrm{s}$ menghasilkan efisiensi listrik sebesar 3,206-3,106\%.

Pada menit ke-5, temperatur panel surya tanpa pendinginan mencapai $40,6^{\circ} \mathrm{C}$ dengan efisiensi sebesar $3,103 \%$. Pada menit yang sama dengan pendinginan kecepatan udara $2 \mathrm{~m} / \mathrm{s}$ temperatur turun menjadi $36,1{ }^{\circ} \mathrm{C}$ dengan efisiensi sebesar 3,158\%. Dalam hal ini terjadi penurunan temperatur dan peningkatan daya yang lebih baik dengan kecepatan udara 3,4 dan $5 \mathrm{~m} / \mathrm{s}$. sehingga didapatkan penurunan temperatur paling besar $34,9^{\circ} \mathrm{C}$ dengan efisiensi sebesar $3,175 \%$.

Jika diambil sampel di menit ke-5 pada pengujian dengan menggunakan pendinginan kecepatan udara $2 \mathrm{~m} / \mathrm{s}$ efisiensi listrik yang didapat adalah $3,158 \%$ sedangkan dengan menggunakan pendinginan kecepatan udara $5 \mathrm{~m} / \mathrm{s}$ efisiensi listrik yang didapat meningkat menjadi 3,175\% kenaikan efisiensi yang terjadi sebesar $0,023 \%$. Kenaikan ini relatif kecil dikarenakan pada panel surya digunakan masih cover dari bahan plastic yang tidak bisa dilepas, sehingga menghambat proses perpindahan panas.

Dapat disimpulkan bahwa semakin besar kecepatan udara maka efisiensi yang dihasilkan juga akan semakin besar. Hal ini dikarenakan temperatur panel turun seiring kenaikan kecepatan udara. hal ini juga diperkuat oleh penelitian lainnya yang menyebutkan bahwa peningkatan rata-rata efisiensi listrik yang paling besar terjadi pada saat penurunan rata-rata temperature paling rendah [6], [14]. Disamping itu, dari Gambar 4 dan 5 dapat dilihat bahwa daya keluaran dan efisiensi di setiap kecepatan, terlihat menurun. Hal ini dikarenakan temperatur panel yang meningkat, sedang pendinginan yang terjadi belum mampu menjaga kondisi temperatur panel seperti di awal pengujian.

\section{Kesimpulan}

Dalam pengujian menggunakan pendinginan menghasilkan rata-rata efisiensi sebesar 3,151\%. Kenaikan kecepatan udara dengan interval $1 \mathrm{~m} / \mathrm{s}$ akan menghasilkan nilai rata-rata penurunan temperatur sebesar $0,7^{\circ} \mathrm{C}$ dan nilai rata-rata kenaikan daya output sebesar 0,03watt serta nilai rata-rata kenaikan efisiensi listrik panel surya sebesar 0,02 $\%$. Sementara tanpa menggunakan pendingin, rata-rata efisiensi yang dihasilkan adalah 3,065\%. Maka dapat disimpulkan bahwa pengujian panel surya dengan menggunakan pendinginan udara lebih efisien dibandingkan dengan panel surya tanpa pendinginan serta perubahan kecepatan udara mempengaruhi temperatur, daya output dan efisiensi listrik dari panel surya.

\section{Daftar Pustaka}

[1] R. Subagyo and I. A. Saga, "Pembuatan Bioetanol Berbahan Baku Kulit Singkong Dan Kulit Nanas Dengan Variasi Massa Ragi," Sci. J. Mech. Eng. Kinemat., vol. 4, no. 1, pp. $1-14,2019$.

[2] O. F. Arifin, M., Margareta, D. O., \& Trimaryana, "Pengaruh Intensitas Cahaya terhadap Efisiensi Konversi Sel Surya Berbasis Dye-Sensitized Solar Cell (DSSC).," J. Integr., vol. 9, no. 1, p. 24, 2017.

[3] S. Kalogirou, The potential of solar industrial process heat applications, 76(4). 2003.

[4] S. Mahdy, M. Reza, and C. Ekaputri, "Mempengaruhi Kinerja Photovoltaic Jenis Polycristalline Berukuran 6Cm X $11 \mathrm{Cm}$ X $0.25 \mathrm{Cm}$ Analyze of Characteristic and External Factors Which Influencing of Polycristalline Photovoltaic Works With the Size $6 \mathrm{Cm}$ X $11 \mathrm{Cm}$ X $0.25 \mathrm{Cm}$," vol. 5, no. 3, pp. 3816-3822, 2018. 
[5] A. D. Biodun, A. D. Kehinde, and O. T. Aminat, "Experimental Evaluation of the Effect of Temperature on Polycrystalline and Monocrystalline Photovoltaic Modules," IOSR J. Appl. Phys., vol. 09, no. 02, pp. 5-10, 2017.

[6] S. Nižetić, D. Čoko, A. Yadav, and F. Grubišić-Čabo, "Water spray cooling technique applied on a photovoltaic panel: The performance response," Energy Convers. Manag., vol. 108, pp. 287-296, 2016.

[7] N. Choubineh, H. Jannesari, and A. Kasaeian, "Experimental study of the effect of using phase change materials on the performance of an air-cooled photovoltaic system," Renew. Sustain. Energy Rev., vol. 101, no. November 2018, pp. 103-111, 2019.

[8] K. Sukarno, A. S. A. Hamid, H. Razali, and J. Dayou, "Evaluation on cooling effect on solar PV power output using Laminar $\mathrm{H} 2 \mathrm{O}$ surface method," Int. J. Renew. Energy Res., vol. 7, no. 3, pp. 1213-1218, 2017.

[9] H. Alizadeh, R. Ghasempour, M. B. Shafii, M. H. Ahmadi, W. M. Yan, and M. A. Nazari, "Numerical simulation of PV cooling by using single turn pulsating heat pipe," Int. J. Heat Mass Transf., vol. 127, pp. 203-208, 2018.

[10] H. Isyanto, Budiyanto, Fadliondi, and P. G. Chamdareno, "Pendingin untuk peningkatan daya keluaran panel surya," Semin. Nas. Sains dan Teknol. 2017, no. November, pp. 1-2, 2017.
[11] N. Tan Jian Wei, W. Jian Nan, and C. Guiping, "Experimental study of efficiency of solar panel by phase change material cooling," IOP Conf. Ser. Mater. Sci. Eng., vol. 217 , no. $1,2017$.

[12] D. Almanda and D. Bhaskara, "Studi Pemilihan Sistem Pendingin pada Panel Surya Menggunakan Water Cooler, Air Mineral dan Air Laut," Resist. (Elektronika Kendali Telekominakasi Tenaga List. Komputer), vol. 1, no. 2, 2018.

[13] P. R. Ansyah, J. Waluyo, Suhanan, M. Najib, and F. Anggara, "Thermal behavior of melting paraffin wax process in cylindrical capsule by experimental study," AIP Conf. Proc., vol. 2001, 2018.

[14] M. Schmidt, I. Astrouski, M. Reppich, and M. Raudensky, "Solar panel cooling system with hollow fibres," Appl. Sol. Energy (English Transl. Geliotekhnika), vol. 52, no. 2, pp. 86-92, 2016.

[15] P. H. Rizal, T. A., Amin, M., \& Saputra, "Kaji Eksperimental Pendinginan Panel Surya Menggunakan Media Udara," Jurutera, vol. 1, no. 1, pp. 027-030, 2014.

[16] T. N. Robby, M. Ramdhani, and C. Ekaputri, "Alat Ukur Kecepatan Angin , Arah Angin , Dan Ketinggian," $e$ Proceeding Eng., vol. 4, no. 2, pp. 1457-1466, 2017.

[17] A. Hasyim Asy'ari, Jarmiko, "Intensitas Cahaya Matahari Terhadap Daya Keluaran Panel Sel Surya," Simp. Nas. RAPI XI FT UMS, p. 57, 2012. 